ISSN 0258-7122

Bangladesh J. Agril. Res. 37(2): 215-223, June 2012

\title{
STUDY ON INTERCROPPING CARROT WITH GROUNDNUT UNDER DIFFERENT ROW ARRANGEMENTS
}

\author{
M. R. I. MONDAL ${ }^{1}$, F. BEGUM ${ }^{2}$ AND M. M. ALAM ${ }^{3}$
}

\begin{abstract}
An experiment was conducted at Agricultural Research Station of BARI, Burirhat, Rangpur during two consecutive seasons of 2004-05 and 2005-06, respectively, to find out suitable row arrangement of carrot with groundnut for higher yield and economic return. There were six treatments, such as sole groundnut, sole carrot, one row of carrot in between two normal rows of groundnut, two rows of carrot in between two normal rows of groundnut, two rows of groundnut alternated with two rows of carrot and three rows of groundnut alternated with three rows of carrot. Results showed that monoculture produced the highest yields of individual crops but in intercropping system the highest groundnut equivalent yield (10.63 t/h and $11.10 \mathrm{t} / \mathrm{ha}$ ) was obtained from two rows of carrot in between two rows of groundnut. The maximum land equivalent ratio (1.67 and 1.74), the highest gross return (Tk.212600/ha and Tk. 248400/ha) and net return (Tk.184881/ha and Tk.211680) were also obtained from the intercropping treatment with two rows carrot in between two normal rows of groundnut. But due to higher cost in this treatment, maximum benefit cost ratio (7.09 and 7.01) was obtained from the intercropping treatment with one row carrot in between two normal rows of groundnut in both the years.
\end{abstract}

Keyword: Intercropping, groundnut, carrot, yield and economic return.

\section{Introduction}

Intercropping is a traditional method of crop production and recognized as a potentially beneficial system of crop production. It increases total production in addition to stabilization of production in the rainfed areas (Rao and Willey, 1980). Intercropping provides an opportunity to avoid crop competition and advantages of increased production (Rahman, 1999 and Mondal et al., 1999) and greater profit margin (Evans, 1960; Grimes, 1963) and gives higher resource use efficiency (Hashem and Moniruzzaman, 1986). Rearrangement of rows, spacing and plant population are some of the important techniques that help to increase the yield of intercrop. By adopting appropriate standard planting geometry in the intercropping system, the total productivity can be enhanced (Umrani et al., 1984). Groundnut is an important oilseed crop of Bangladesh and it is sown in sandy loam soil during November to December in the river banks after receding flood water. The rate of seed germination and seedling growth are very slow due

${ }^{1}$ Director General, Bangladesh Agricultural Research Institute (BARI), Gazipur, ${ }^{2}$ Senior Scientific Officer, Oilseed Research Centre, BARI, Gazipur, ${ }^{3}$ Scientific Officer, Oilseed Research Centre, BARI, Gazipur, Bangladesh. 
to prevailing low temperature and it continues up to February. The plant growth becomes rapid with the increase of temperature. The space between two rows of groundnut at early stage may be utilized by planting any short stature crop as intercrop. Intercropping system gives higher cash return, increased total production and per unit yield than growing sole crop (Kurata, 1966).

Carrot (Daucus carota L.) is an important vegetable crop, which contains high carotene. In Bangladesh, carrot is usually sown in the month of November and December in sandy loam type of soil. It is a short duration crop; which can be grown as intercrop with groundnut. Both groundnut and carrot are row seeded crops and it is grown in the same season. Carrot can be cultivated as intercrop by utilizing space between two rows of groundnut. So, an experiment was undertaken to find out the suitable row arrangement for intercropping groundnut with carrot for higher yield and economic return.

\section{Materials and Method}

An experiment was conducted at Agricultural Research Station, BARI, Burirhat, Rangpur during rabi seasons of 2004-05 and 2005-06, respectively. The experimental area was a piece of well drained medium high land with moderately even topography. The area belongs to Tista Floodplain (AEZ-3), having low organic matter (1.23\%) and deficient in nitrogen $\left(0.068 \mathrm{NH}_{4}-\mathrm{N}(\mu \mathrm{g} / \mathrm{g})\right.$, phosphorus $(12.5 \mu \mathrm{g} / \mathrm{g})$ and $\mathrm{Ca}(1.5 \mathrm{Meq} / 100 \mathrm{~g})$ in comparison with the standard nutrient status. The soil is acidic in nature having $\mathrm{P}^{\mathrm{H}} 4.6$ with low O.M(1.21$1.25 \%)$ content.

Experiments were conducted in the field of ARS Burirhat, Rangpur during rabi seasons of 2004-05 and 2005-06. Treatments were included $-\mathrm{T}_{1}=$ Sole groundnut, $T_{2}=$ Sole carrot, $T_{3}=$ One row of carrot in between two normal rows of groundnut ( $2 \mathrm{G}: 1 \mathrm{C}), \mathrm{T}_{4}=$ Two rows of carrot in between two normal rows of groundnut (2G:2C), $T_{5}=$ Two rows of groundnut alternated with two rows of carrot $(2 \mathrm{G}: 2 \mathrm{C})$ and $\mathrm{T}_{6}=$ Three rows of groundnut alternated with two rows of carrot (3G : 3C).

The experiment was laid out in a randomized complete block design with three replications having plot size $3 \mathrm{~m} \times 4 \mathrm{~m}$. Fertilizers were applied at the rate of 30, 100, 30, 30, and $4 \mathrm{~kg} / \mathrm{ha}$ of $\mathrm{N}, \mathrm{P}_{2} \mathrm{O}_{5}, \mathrm{~K}_{2} \mathrm{O}, \mathrm{S}$, and $\mathrm{Zn}$, respectively, for groundnut (Sole) and 50, 25, 40, and $10 \mathrm{~kg} / \mathrm{ha}$ of $\mathrm{N}, \mathrm{P}_{2} \mathrm{O}_{5}, \mathrm{~K}_{2} \mathrm{O}$ and $\mathrm{S}$, respectively, for carrot (Sole); and 30, 100, 30, 30, and $4 \mathrm{~kg} / \mathrm{ha}$ of $\mathrm{N}, \mathrm{P}_{2} \mathrm{O}_{5}, \mathrm{~K}_{2} \mathrm{O}$, $\mathrm{S}$, and $\mathrm{Zn}$, respectively, for intercropping plots in the form of urea, triple super phosphate, muriate of potash, gypsum, and boric acid. All the fertilizers were incorporated in the soil at the time of final land preparation for sole groundnut plots. But all the fertilizers and one third of urea were applied during final land preparation and remaining two thirds of the urea was top dressed in the sole 
carrot and intercropped plots in two installments at 25 and 45 DAE. The groundnut variety BARI Chinabadam-6 and carrot variety Pusha Kashore were used for the experiment. Seeds @ $110 \mathrm{~kg} / \mathrm{ha}$ of groundnut and $2.5 \mathrm{~kg} / \mathrm{ha}$ were sown on 25-11-2004 and 20-11-2005, respectively. Spacing of sole groundnut and sole carrot were $40 \mathrm{~cm} \times 15 \mathrm{~cm}$ and $30 \mathrm{~cm} \times 10 \mathrm{~cm}$, respectively. Two irrigations were applied at 25 and 50 days after emergence (DAE) and other intercultural operations were done as per requirement. At maturity, ten randomly selected plants of carrot and groundnut were uprooted from each plot for post harvest data collection. Data were collected on plant height, number of branches/plant, number of pods/plant, 1000-seed weight, pod yield/plant and pod yield/ha for groundnut; and plant height, root length, root diameter and yield for carrot. Crops were harvested as whole plot basis and yields were converted to t/ha. Collected data were statistically analysed separately compared by using Least Significant Difference (LSD) test (Steel \& Torrie, 1960) and land equivalent ratio (LER) values were computed from the yield data of the crops (Shaner et al., 1982).

LER $=\frac{\text { Intercropped yield of groundnut }}{\text { Sole crop yield of groundnut }}+\frac{\text { Sole crop yield of groundnut }}{\text { Sole crop yield of carrot }}$

Economic analyses have been presented in Table 4 . Yield of individual crop was converted into groundnut equivalent yield (GEY) on the basis of the prevailing market price of the products.

GEY $=$ Yield of intercrop groundnut $+\frac{\text { Yieldof intercropcarrot } X \text { priceof carrot }}{\text { Priceof groundnut }}$

\section{Results and Discussion}

\section{Yield and yield attributes of groundnut}

Yield and yield attributes of groundnut as influenced by different intercropping treatments are presented in Table 1. Plant height, number of pods/plant, pod yield/plant and pod yield/ha were significantly affected when grown in different arrangements with carrot but number of branches/plant and 1000-seed weight were non-significant in both the years. The maximum plant height and number of branches/plant were recorded from three rows of groundnut alternated with two rows of carrot treatment. Higher number of pods and pod yields/plant were obtained from the sole plot of groundnut $\left(T_{1}\right)$ followed by $T_{3} \& T_{6}$. The maximum pod yield (2.01 and $2.8 \mathrm{t} / \mathrm{ha}$ ) were obtained from the plot of sole groundnut in both the years (Table 1). The highest pod yield of groundnut from sole plot might be due to higher number of pods/plant and pod yield/plant. The highest pod yield from the sole plot also reported by Hashem and Monoruzzaman (1986), Shindi et al. (1989), Senthivel et al. (1989) Mondal et al. (1999), Begum et al. (2000) and Mondal et al (2004) 
Table 1. Pod yield and yield attributes of groundnut as influenced by intercropping groundnut and carrot at ARS, $\underset{\infty}{\sim}$ Burirhat, Rangpur during rabi Seasons, 2004-05 and 2005-2006.

\begin{tabular}{|c|c|c|c|c|c|c|c|c|c|c|c|c|}
\hline \multirow{2}{*}{ Treatment } & \multicolumn{2}{|c|}{$\begin{array}{l}\text { Plant height } \\
\text { (cm) }\end{array}$} & \multicolumn{2}{|c|}{$\begin{array}{c}\text { No. of branches/ } \\
\text { plant }\end{array}$} & \multicolumn{2}{|c|}{$\begin{array}{l}\text { No. of pods/ } \\
\text { plant }\end{array}$} & \multicolumn{2}{|c|}{$\begin{array}{l}\text { 1000- seed wt } \\
\text { (g) }\end{array}$} & \multicolumn{2}{|c|}{$\begin{array}{l}\text { Pod yield/ } \\
\text { plant (g) }\end{array}$} & \multicolumn{2}{|c|}{$\begin{array}{l}\text { Pod yield } \\
\text { (t/ha) }\end{array}$} \\
\hline & $\begin{array}{l}1 \mathrm{st} \\
\mathrm{yr}\end{array}$ & $\begin{array}{c}\text { 2nd } \\
\mathrm{yr}\end{array}$ & $\begin{array}{l}1 \mathrm{st} \\
\mathrm{yr}\end{array}$ & $\begin{array}{c}\text { 2nd } \\
\mathrm{yr}\end{array}$ & $\begin{array}{l}1 \mathrm{st} \\
\mathrm{yr}\end{array}$ & $\begin{array}{l}\text { 2nd } \\
\text { yr }\end{array}$ & $\begin{array}{l}1 \mathrm{st} \\
\mathrm{yr}\end{array}$ & $\begin{array}{l}\text { 2nd } \\
\text { yr }\end{array}$ & $\begin{array}{l}1 \mathrm{st} \\
\mathrm{yr}\end{array}$ & $\begin{array}{c}\text { 2nd } \\
\mathrm{yr}\end{array}$ & $\begin{array}{l}1 \mathrm{st} \\
\mathrm{yr}\end{array}$ & $\begin{array}{c}\text { 2nd } \\
\mathrm{yr}\end{array}$ \\
\hline $\mathrm{T}_{1}=$ Sole G.nut & 47 & 42 & 9.2 & 8.1 & 20.00 & 17.8 & 541 & 515 & 85.00 & 88.0 & 2.01 & 2.8 \\
\hline $\begin{aligned} \mathrm{T}_{3}= & 2 \text { rows g.nut in } \\
& \text { between } 1 \text { row carrot }\end{aligned}$ & 38 & 42 & 11.4 & 10.54 & 19.20 & 16.6 & 563 & 512 & 75.00 & 75.3 & 1.15 & 2.0 \\
\hline $\begin{aligned} \mathrm{T}_{4}= & 2 \text { rows g.nut in } \\
& \text { between } 2 \text { rows carrot }\end{aligned}$ & 40 & 36 & 9.5 & 8.9 & 15.83 & 15.9 & 566 & 509 & 70.00 & 74.3 & 1.55 & 1.65 \\
\hline $\begin{array}{c}\mathrm{T}_{5}=2 \text { rows g.nut alternate } \\
2 \text { rows carrot }\end{array}$ & 40 & 41 & 9.6 & 9.0 & 14.26 & 14.0 & 548 & 510 & 66.66 & 67.3 & 1.36 & 1.45 \\
\hline $\begin{array}{c}\mathrm{T}_{6}=3 \text { rows g.nut alternate } \\
3 \text { rows carrot }\end{array}$ & 52 & 43 & 12.3 & 11.2 & 16.46 & 16.0 & 558 & 500 & 70.00 & 77.3 & 1.28 & 1.5 \\
\hline CV (\%) & 10.13 & 7.07 & 8.19 & 7.89 & 11.90 & 10.73 & 7.14 & 2.20 & 5.11 & 4.04 & 1.62 & 1.20 \\
\hline LSD (0.05) & 6.25 & 5.47 & NS & NS & 5.68 & 3.39 & NS & NS & 8.01 & 3.21 & 0.85 & 0.75 \\
\hline
\end{tabular}

- $\quad$ G.nut $=$ Groundnut

1 st year $=2004-05$

$2^{\text {nd }}$ year $=2005-06$ 
Table 2. Yield and yield attributes of carrot as influenced by intercropping groundnut with carrot during rabi seasons of 2004-05 and 2005-06 at ARS, Burirhat, Rangpur.

\begin{tabular}{|c|c|c|c|c|c|c|c|c|c|c|}
\hline \multirow{2}{*}{ Treatment } & \multicolumn{2}{|c|}{$\begin{array}{l}\text { Plant height } \\
\quad(\mathrm{cm})\end{array}$} & \multicolumn{2}{|c|}{ Root length (cm) } & \multicolumn{2}{|c|}{$\begin{array}{l}\text { Root diameter } \\
\quad(\mathrm{cm})\end{array}$} & \multicolumn{2}{|c|}{ Root wt (g) } & \multicolumn{2}{|c|}{$\begin{array}{l}\text { Root yield } \\
\text { (t/ha) }\end{array}$} \\
\hline & $\begin{array}{l}1 \mathrm{st} \\
\mathrm{yr}\end{array}$ & $\begin{array}{c}\text { 2nd } \\
\mathrm{yr}\end{array}$ & $\begin{array}{l}1 \mathrm{st} \\
\mathrm{yr}\end{array}$ & $\begin{array}{l}\text { 2nd } \\
\mathrm{yr}\end{array}$ & $\begin{array}{l}1 \mathrm{st} \\
\mathrm{yr}\end{array}$ & $\begin{array}{l}\text { 2nd } \\
\mathrm{yr}\end{array}$ & $\begin{array}{l}1 \mathrm{st} \\
\mathrm{yr}\end{array}$ & $\begin{array}{l}\text { 2nd } \\
\text { yr }\end{array}$ & $\begin{array}{l}1 \mathrm{st} \\
\mathrm{yr}\end{array}$ & $\begin{array}{c}\text { 2nd } \\
\text { yr }\end{array}$ \\
\hline $\mathrm{T}_{2}=$ Sole carrot & 46 & 39.5 & 14.36 & 12.5 & 4.6 & 3.21 & 114.33 & 116 & 22.61 & 18.82 \\
\hline $\begin{array}{c}\mathrm{T}_{3}=2 \text { rows g.nut in between } \\
1 \text { row carrot }\end{array}$ & 44 & 35.4 & 13.80 & 12.1 & 4.4 & 3.15 & 108.33 & 107 & 13.88 & 15.0 \\
\hline $\begin{array}{c}\mathrm{T}_{4}=2 \text { rows g.nut in between } \\
2 \text { row carrot }\end{array}$ & 42 & 37.2 & 12.86 & 12.0 & 4.2 & 2.63 & 105.76 & 95 & 18.69 & 16.0 \\
\hline $\begin{array}{c}\mathrm{T}_{5}=2 \text { rows g.nut alternate } \\
2 \text { rowss carrot }\end{array}$ & 35 & 34.2 & 11.00 & 12.3 & 4.0 & 2.69 & 85.63 & 84 & 15.98 & 14.1 \\
\hline $\begin{array}{c}\mathrm{T}_{6}=3 \text { rows g.nut alternate } \\
3 \text { rows carrot }\end{array}$ & 40 & 37.5 & 12.60 & 10.9 & 4.1 & 2.63 & 83.62 & 93 & 12.15 & 12.5 \\
\hline CV (\%) & 4.84 & 7.77 & 11.11 & 11.42 & 7.80 & 10.42 & 10.01 & 13.70 & 10.33 & 8.4 \\
\hline LSD (0.05) & 1.66 & 5.34 & 1.91 & 1.58 & 0.41 & 0.62 & 20.5 & 28.1 & 2.81 & 2.53 \\
\hline
\end{tabular}


Table 3. Yield, Groundnut Equivalent yield and economic analysis of groundnut and carrot intercropping during rabi $\underset{\mathscr{O}}{\mathbb{N}}$ season 2004-05 and 2005-06 at ARS, Burirhat, Rangpur.

\begin{tabular}{|c|c|c|c|c|c|c|c|c|c|c|c|c|c|}
\hline \multirow[t]{2}{*}{ Treatment } & \multicolumn{2}{|c|}{$\begin{array}{l}\text { Groundnut } \\
\text { equivalent } \\
\text { yield (t/ha) }\end{array}$} & \multicolumn{2}{|c|}{ LER } & \multicolumn{2}{|c|}{$\begin{array}{c}\text { Gross return } \\
\text { (Tk./ha) }\end{array}$} & \multicolumn{2}{|c|}{$\begin{array}{l}\text { Cost of } \\
\text { cultivation } \\
\text { (Tk./ ha) }\end{array}$} & \multicolumn{2}{|c|}{$\begin{array}{l}\text { Net return } \\
\text { (Tk./ha) }\end{array}$} & \multicolumn{3}{|c|}{ BCR } \\
\hline & $\begin{array}{l}1 \mathrm{st} \\
\mathrm{yr}\end{array}$ & $\begin{array}{l}\text { 2nd } \\
\text { yr }\end{array}$ & $\begin{array}{l}1 \mathrm{st} \\
\mathrm{yr}\end{array}$ & $\begin{array}{c}\text { 2nd } \\
\mathrm{yr}\end{array}$ & $\begin{array}{l}1 \mathrm{st} \\
\mathrm{yr}\end{array}$ & $\begin{array}{c}\text { 2nd } \\
\mathrm{yr}\end{array}$ & $\begin{array}{l}1 \mathrm{st} \\
\mathrm{yr}\end{array}$ & $\begin{array}{c}\text { 2nd } \\
\mathrm{yr}\end{array}$ & $\begin{array}{l}1 \mathrm{st} \\
\mathrm{yr}\end{array}$ & $\begin{array}{c}\text { 2nd } \\
\mathrm{yr}\end{array}$ & $\begin{array}{l}1 \mathrm{st} \\
\mathrm{yr}\end{array}$ & $\begin{array}{c}\text { 2nd } \\
\mathrm{yr}\end{array}$ & Average \\
\hline $\mathrm{T}_{1}=$ Sole $\mathrm{G}$.nut & 2.01 & 2.80 & 1.00 & 1.00 & 42,200 & 56,000 & 10,600 & 14,500 & 31600 & 41,500 & 3.98 & 3.86 & 3.92 \\
\hline $\mathrm{T}_{2}=$ Sole carrot & 11.31 & 12.42 & 1.00 & 1.00 & $1,13,100$ & $1,88,000$ & 25138 & 30,800 & 87,962 & 155200 & 4.50 & 6.10 & 5.3 \\
\hline $\begin{array}{l}\mathrm{T}_{3}=2 \text { rows g.nut } \\
\text { in between } 1 \text { row } \\
\text { carrot }\end{array}$ & 9.41 & 11.00 & 1.48 & 1.21 & $1,88,000$ & $2,20,000$ & 26505 & 31,370 & $1,61,495$ & 186630 & 7.09 & 7.01 & 7.05 \\
\hline $\begin{array}{l}\mathrm{T}_{4}=2 \text { rows g.nut } \\
\text { in between } 2 \\
\text { row carrot }\end{array}$ & 10.63 & 11.10 & 1.67 & 1.74 & $2,12,600$ & $2,48,400$ & 30400 & 36,720 & 182200 & 211680 & 6.99 & 6.76 & 6.87 \\
\hline $\begin{array}{l}\mathrm{T}_{5}=2 \text { rows g.nut } \\
\text { alternate } 2 \text { rows } \\
\text { carrot }\end{array}$ & 9.54 & 9.41 & 1.59 & 1.66 & $1,90,800$ & $2,22,000$ & 27700 & 35,119 & 163100 & 186881 & 6.89 & 6.32 & 6.60 \\
\hline $\begin{array}{l}\mathrm{T}_{6}=3 \text { rows g.nut } \\
\text { alternate } 3 \text { rows } \\
\text { carrot }\end{array}$ & 9.03 & 9.50 & 1.18 & 1.18 & $1,88,600$ & $1,90,000$ & 30800 & 37,895 & 149800 & 152105 & 5.86 & 5.01 & 5.43 \\
\hline
\end{tabular}

Price of non-seed groundnut and carrot
\begin{tabular}{|l|l|}
\hline \multicolumn{1}{|c|}{$\mathbf{2 0 0 4 - 0 5}$} & $\mathbf{2 0 0 5 - 0 6}$ \\
\hline Groundnut @ Tk.20.00/kg & $@$ Tk.20.00/kg \\
& \\
\hline Carrot @Tk.10.00/kg & @ Tk.12.00/kg \\
\hline
\end{tabular}




\section{Yield and yield attributes of carrot}

Yield attributes of carrot, such as plant height, root length, root diameter, root weight and root yield/ha were significantly influenced by different treatments in both the years (Table 3). The maximum plant height $(46.0 \mathrm{~cm} \mathrm{\&} 39.5 \mathrm{~cm})$, root length $(14.36 \mathrm{~cm} \mathrm{\&} 12.50 \mathrm{~cm})$, root diameter $(4.60 \mathrm{~cm} \& 3.21 \mathrm{~cm})$, and root weight $(114 \mathrm{~g} \& 116 \mathrm{~g})$ were recorded from sole plots. Maximum yield reduction was recorded from 3 rows of groundnut and carrot; and minimum from 1 row groundnut and 2 rows carrot. Yield was reduced with the increase of carrot rows. The highest root yield/ha ( $22.61 \mathrm{t} / \mathrm{ha} \& 18.82 \mathrm{t} / \mathrm{ha}$ ) were found in sole carrot plot. The highest yield from sole carrot plot might be due to higher length of root, diameter of root and root weight. (Table 2). The second highest yield (18.69 $\mathrm{t} / \mathrm{ha}$ and $16.0 \mathrm{t} / \mathrm{ha}$ ) were recorded from the plots of two rows of carrot in between two normal rows of groundnut.

\section{Cost Benefit Analysis}

\section{Groundnut equivalent yield (GEY):}

All the intercropped combinations showed higher groundnut equivalent yield than sole groundnut. Results showed that the highest groundnut equivalent yield $11.31 \mathrm{t} / \mathrm{ha} \& 12.42 \mathrm{t} /$ ha were obtained from sole carrot treatment $\left(\mathrm{T}_{2}\right)$ in both the years. Among the intercrops, the groundnut equivalent yield varied from 9.41 to $11.10 \mathrm{t} /$ ha with the highest (10.63 to 11.1 ) from two rows of carrot in between two normal rows of groundnut. Carrot yield reduced significantly resulting lower GEY in all the intercropping treatments (Table 4).

\section{Land equivalent ratio (LER)}

The LER is the total land required by the sole crop to produce as much yield as can be obtained from an intercropping system. All the intercrop combinations showed the higher LER over sole crops. Results showed that the highest LER (1.67 \& 1.74) were obtained from two rows of carrot in between two normal rows of groundnut (Table 4). The LER value of $1.67 \& 1.74$ indicated that by intercropping groundnut with carrot, the productivity of groundnut could be increased upto 67 and $74 \%$ over the sole groundnut. It also indicates that by intercropping groundnut with carrot, a farmer could produce 1.55 and $1.65 \mathrm{t} / \mathrm{ha}$ groundnut and 18.69 and $16.0 \mathrm{t} / \mathrm{ha}$ carrot from one hectare of land instead of growing them separately in 1.67 and 1.74 hectares of land to obtained the same yield. These results are in conformity with the findings of Quayyum et al. (1987), Hashem et al. (1990) and Hossain and Bari, (1996). 


\section{Cost Benefit Analysis}

An analysis on cost and return of intercropping groungnut with carrot has been given in Table 4. All the intercropping systems showed higher gross and net return than either groundnut \& carrot grown as sole crop. The highest gross return (Tk.212600 \& Tk.248400/ha) and net return (Tk.182200 \& Tk.211680/ha) were recorded from 2 rows carrot in between 2 rows of groundnut $\left(\mathrm{T}_{3}\right)$ but maximum BCR (7.09 \& 7.01 ) were obtained from the treatment with one row of carrot in between two normal rows of groundnut in both the years (Table 4). Among the intercropped combinations, higher gross return were recorded from the treatment $\mathrm{T}_{4}$ but it was showed lower BCR than $\mathrm{T}_{3}$ treatment due to higher cost of cultivation. Similar economic advantages of intercropping have also been reported by Hashem et al. (1990) and Hossain and Bari (1996) and Khaliq et al. (1997).

Significant results showed that groundnut grown as intercrop with carrot is more profitable than grown groundnut alone. The results also suggest the possibility of obtaining a reasonable good yield and profitable economic return from intercropping groundnut with carrot having the row arragement of one row of carrot in between two normal rows of groundnut.

\section{References}

Begum. F, M.A. Akhtaruzzaman; S.M.Raquibllah F. Kamal and M.A. Hossain. 2000. Influence of different plough on intercropping maize leafy vegetables. Bangladesh J. Agril. Res. 25(2): 253-260

Evans, A.C. 1960. Studies on the intercropping maize and sorghum with groundnut. East Afr. Agri. J. 26: 1-10

Grimes, B.C. 1963. Intercropping and alternate row cropping of cotton and maize. East Afr. Agri. J. 28(3): 161-163.

Hashem. A. and A.F.M. Moniruzzaman. 1986. Effect of intercropping maize with cowpea at varying plant population levels. Bangladesh Agron. J. 1:25-39.

Hashem, A., A.F.M. Moniruzzaman and M.A. Akhtaruzzaman. 1990. Study on the productivity, profitability of potato intercropped with vegetables and relayed with onion. Bangladesh Agron. J. 3: 39-13.

Hossain, M.A. and A.K.M.A. Bari. 1996. Effect of intercropping groundnut with garlic at varying plant population levels. Bangladesh Hort. 24 (1\&2): 29-34.

Khaliq, Q.A. D.J. Costa and M.H.K. Howlader 1997. Production potentiality of chilli intercropped with cowpea. Bangladesh Agron. J. 7(1\&2): 15-19.

Kurata,T. 1966. A study on the farming systems in USSR. Quarterly J. Agro.Econ. 9 (3): 179-205.

M.R.I. Mondal, F. Begum and S. M. Raquibullah. 2004. Study on intercropping groundnut with onion. J. Agric. Rural Dev. 2(1), 83-88.

M.R.I. Mondal, F. Begum and Abul Hossain. 2004. Study on intercropping groundnut with garlic. Bangladesh J. Agril. Res. 29(3). 
Mondal, M.R.I., A.S.M. M.R. Khan., M. Akkas Ali., M. Nozrul Islam and M. A. Mannan. 1999. A study on intercropping sesame with groundnut. Bangladesh J. Agril. Res. 24(4): 657- 662.

Quayyum, M.A., M.E. Akanda and M.F. Karim 1987. Row spacing and number of rows of chickpea grown in association with maize. Bangladesh J. Agril. 12: 223-230.

Rahman , M.A.1999. Comperative performance of intercropping of pulse and. oilseeds with rainfed wheat (Triticum aestivum)in Bangladesh. Indian J. Agron. 44(3): 504-508

Rao, M.R. and R.W. Willey. 1980. Evaluation of yield stability intercropping studies on sorghum-pigeonpea. Expt. Agric. 16(2): 105-116.

Senthivel, T., P.W. Parames., M. Arumugam and T. Ramanathan. 1989. An ideal intercropping system for rainfed groundnut in Tamil Nadu. Indian J. Agri. Sci. 59(7): 437-439.

Shindi, S.H. V.G. Danwate, P.S. Pol and N.K. Umrani 1989. Productivity of pigeonpea and groundnut intercropping systems. Indian J. Agron. 34(4): 484-486.

Umrani, N.K., Shinde and P.M. Dhonde. 1984. Studies on intercropping of pulses in kharif sorghum. Indian J. Agron. 29(1): 27-30.

Steel, R.G.D and J. H. Torrie. 1960. Principles and procedures of statistics, McGrow Hill Book Co. Inc. New York. Toronto. London . pp. 107-109. 